\title{
O PENSAMENTO ILUMINISTA E O DESENCANTAMENTO DO MUNDO: Modernidade e a Revolução Francesa como marco paradigmático
}

\section{THE ILLUMINIST THOUGHT AND THE DISENCHANTMENT OF THE WORLD: Modernity and the French Revolution as paradigmatic landmark}

Vico Denis S. de Mello*

Manuella Riane A. Donato*

RESUMO: Tem-se, a partir da ascensão do pensamento filosófico e científico, em meados do século XVI, uma mudança acerca da funcionalidade da ciência e do lugar do indivíduo no mundo. Mas essa alteração só foi possível através da expansão do iluminismo, tendo como marco histórico a Revolução Francesa. Como frutos desses novos paradigmas, encontram-se: i) a decadência do pensamento clerical; ii) o racionalismo como propulsor do saber, e; iii) o indivíduo recolocado como o centro do conhecimento universal. À esta ruptura paradigmática convencionou-se chamar de Modernidade. Portanto, o presente trabalho busca analisar conceitualmente a evolução e consolidação do pensamento iluminista e, respectivamente, da Modernidade, além de retratar a Revolução Francesa e sua importância ímpar no percurso histórico ocidental.

Palavras-chave: Passado; Modernidade; lluminismo; Revolução Francesa.

ABSTRACT: From the rise of philosophical and scientific thought, in the mid-sixteenth, there was a change in the functionality of science and the role of individual in the world. But this change was only possible trough the enlightenment's expansion, having the French Revolution as historical landmark. Some results of these paradigms are: i) the decline of clerical thought; ii) the rationalism as propellant of knowledge, and; iii) the individual as the center of universal knowledge. This paradigmatic rupture was called Modernity. Therefore, this paper aims to analyze the evolution and consolidation of enlightenment thought and respectively of Modernity, beyond discuss the French Revolution and its importance in the western history path.

Palavras-chave: Past; Modernity; Enlightenment; French Revolution.

\section{Introdução}

O presente trabalho busca analisar o processo de mudança da concepção entre antigo/moderno, passado/presente, além de como o iluminismo influenciou sobremaneira na formação de um pensamento hegemônico na sociedade ocidental. Ressalta-se que esse processo começa a ter maior aceitação entre os séculos XVII e XVIII. É nesta época que grandes cientistas e filósofos acabariam por estabelecer e mapear o campo teórico que ainda hoje nos sustentamos.

\footnotetext{
* Bacharel em Relações Internacionais pela Universidade Estadual da Paraíba (UEPB), atualmente é mestrando em Ciência Política pelo PPGCP-UFPE e bolsista CAPES.

** Bacharel em Relações Internacionais pela Faculdade Integrada do Recife. Mestranda em Ciência Política na Universidade Federal de Pernambuco e bolsista CAPES.
} 
Paradigmas consolidados em um primeiro momento no saber eclesiástico - a ideia da providência divina e na escatologia - e, em um segundo momento, no saber científico consolidada pela Revolução Francesa - conjugado com a técnica, que proporcionaria uma mudança drástica no estilo de vida humano. A mudança trazida pela revolução capacitaria 0 "progresso" da sociedade: responsável pela promoção das potencialidades humanas e da condução do conhecimento tecnológico - vivenciados até hoje por nós.

Foi através de pensadores como Copérnico, Galileu, Newton - fundadores da ciência natural - e também por filósofos como Locke, Montesquieu e Rousseau que se deu 0 desenvolvimento do pensamento iluminista. Nesse movimento que iniciou e aprofundou-se 0 processo da transformação social e técnica - em detrimento da metafísica e dos cálculos esotéricos - sem precedentes na história da humanidade.

Era, então, com a popularização da ciência que alcançaríamos um grau de desenvolvimento. Ou seja, este foi

\begin{abstract}
um dos ícones daquele século, que marcou o sucesso definitivo de uma doutrina geral de progresso. 0 avanço da astronomia - com a perda do privilégio cósmico da Terra e a necessidade de admitir que podemos não estar sós no universo tiveram uma profunda influência no pensamento humano. 0 destino universal do homem, defendido pela Igreja, sofreu forte abalo; restava-nos perdidos na imensidão do universo, encontrar uma teoria menos grandiosa para iluminar nosso futuro de habitantes desse pequeno planeta (DUPAS, 2006, p. 40).
\end{abstract}

Processo este, que levou à dissolução dos mitos e a substituição da imaginação pelo saber racional e científico. Dessa forma, terminada a era das explicações metafísicas, a racionalidade acabava por tomar seu lugar com sentido único e absoluto para a validação do conhecimento humano, perdendo a natureza o seu fator de encantamento e receio ao homem e passando a ser sobreposta pelo pensamento racional e técnico da sociedade (ADORNO; HORKHEIMER, 1985; SILVA, 2005).

Todavia, seria só após a Revolução Francesa que este modelo de racionalidade se estenderia mais fortemente às outras nações e sociedades. Paradigmas que acabavam por reconduzir a duas distinções fundamentais do saber: primeiro, o conhecimento científico sobrepondo-se ao conhecimento religioso e do senso comum e; em segundo, entre a natureza e a sociedade. $\mathrm{O}$ conhecimento, portanto, avançaria as fronteiras do imaginário e teria um caráter descomprometido e livre pela observação científica (SANTOS, 1987). 


\section{O Antigo e o Passado}

O antigo e o passado podem ser determinados, a partir de uma visão ocidentalista, dentro de uma percepção da temporalidade histórica e seu processo de transmutação ao longo dos séculos. Estariam ligados diretamente à história da Cristandade, sustentada em dois pilares: a primeira seria a construção do medo, ou seja, a criação de perturbações no imaginário como: medo da noite, dos mares, do "outro", do novo e do "moderno", e; à espera do fim do mundo fundamentado na escatologia.

A Igreja conseguiria afirmar seus preceitos, a partir da ascensão do cristianismo no continente europeu, desde o declínio do Império Romano ao fim da Idade Média. Com a expansão das navegações e das ciências, a idéia de providência continuou como dominantes no continente, mesmo à época da Reforma, onde todos esses formatos estariam ainda ligados à realidade histórica.

E, apesar da Reforma surgir como um movimento de ruptura e de renovação religiosa, ela trazia consigo, também, todos os sinais do provável fim do mundo. Pois, apesar de trazer em suas bases uma renovação dos preceitos religiosos, ela não perdia a característica escatológica, fundamentada na própria bíblia. Chegaria o próprio Lutero ${ }^{1}$ a afirmar frequentemente o breve fim, não tardando mais que um ano. Isso acaba indicando uma abreviação temporal e de grande velocidade, embora permanecesse oculta a data desse possível fim.

A Igreja era a garantia dessa ordem até que viesse o fim do mundo, não podendo, portanto, ser ameaçada a sua unidade. Assim, o futuro do mundo e o seu fim foram incorporados à Igreja. Percebemos através disto que o futuro é integrado ao tempo, mas não se localizando no fim dos tempos. Este último, por entendimento, só pôde ser vivenciado, pois fora colocado em suspensão pela Igreja, permitindo a esta que se perpetuasse como a benfeitora da própria história da salvação.

Entretanto, a celebração da paz religiosa em Augsburg² marcaria o início do processo de derrocada dos partidos religiosos. Baseado na impossibilidade de encontrarem de fato um equilíbrio e união, entre as partes. Nesse sentido, a paz e a unidade religiosa deixariam de ser coisas idênticas. Paz significaria, agora, pacificar as frentes de batalha da guerra civil ou simplesmente congelá-las.

\footnotetext{
${ }^{1}$ Grande idealizador e líder no movimento da Reforma, tendo o seu início na Alemanha e depois espalhada por todo o continente europeu. O movimento de reforma no continente tomou diversas posições, além do luteranismo, como o calvinismo, anglicanismo e o puritanismo.

2 Tratado assinado entre Carlos I da Espanha e as forças da Liga de Esmalcalda - aliança de príncipes protestantes - em 25 de Setembro de 1555, na cidade de Augsburgo, na atual Alemanha.
} 
Tendo em vista a celebração deste acordo, este trazia consigo a necessidade de um novo princípio, o da "política" que viria a se disseminar mais fortemente no século seguinte, a qual os políticos valorizam em seu escopo, somente o temporal e não o eterno. Portanto, o que começara como uma guerra civil religiosa no Sacro Império Romano, terminava com um acordo de paz entre os senhores territoriais.

Retirava-se desse ocorrido uma experiência acerca da idéia do fim dos tempos, reconhecendo-se que as guerras civis religiosas não prenunciariam o Juízo Final. A paz, então, só tornaria possível à medida que as potências religiosas se esgotassem ou se consumissem em luta aberta, à medida que fosse possível cooptá-las politicamente ou neutralizá-las. Iria se constituindo, através destes acontecimentos, em um novo e inédito tipo de futuro.

Nesse sentido, é de constatar que as profecias acerca do fim do mundo, foram sendo adiadas cada vez mais, a partir do século XV. A própria astrologia teria um papel interessante à época, sendo levada ao descrédito com a ascensão das ciências naturais. As ciências naturais deslocavam o fim para um futuro cada vez mais distante, diferentemente das expectativas escatológicas. Por outro ângulo, o Sacro Império Romano-Germânico perdia sua função escatológica, com a formação de novos conceitos - como a de soberania por Bodin, após a Paz de Westfália -, cabendo agora ao Estado a tarefa de manutenção da paz e não de um Império providencial.

Portanto, o cálculo político e a contenção humanista delimitaram um novo horizonte para o futuro. Desta forma, o grande número de presságios em relação ao fim dos tempos e os que previam inúmeros eventos de menor abrangimento, seriam incapazes de prejudicar o curso das coisas humanas. Acabaria por ser inaugurado um tempo diferente e novo.

\section{A Modernidade e o lluminismo}

Essa mudança subjetiva surgiria com a ideia de progresso, de ruptura com o passado tratado brevemente na introdução. E, em geral, se encontraria associada com algum evento significativo tomado como um marco histórico - neste caso, a Revolução Francesa. Estaria por um lado, o prognóstico do racionalismo e, do outro, a filosofia da história. Assim, estes conceitos surgiriam em antagonia às antigas profecias, onde os homens poderiam ser os senhores de seu próprio destino e conhecedor das leis naturais - física e humana. 
Seria, também, com o advento da filosofia da história, a inauguração da possibilidade de interpretação de um futuro inédito à nossa modernidade. Imiscuiria-se também na filosofia do progresso uma mistura entre prognósticos racionais e previsões de caráter salvacionistas. Essa concepção, de acordo com Chauí (2000, p. 59), seria de que

\begin{abstract}
os seres humanos, as sociedades, as ciências, as artes e as técnicas melhoram com 0 passar do tempo, acumulam conhecimento e práticas, aperfeiçoando-se cada vez mais, de modo que o presente é melhor e superior, se comparado ao passado, e o futuro será melhor e superior, se comparado ao presente.
\end{abstract}

Assim, o progresso se desenvolveria na medida em que o Estado e seus prognósticos não fossem mais capazes de satisfazer a exigência soteriológica, e sua motivação seria forte 0 suficiente para chegar a um Estado que, em sua existência, dependesse da eliminação das profecias apocalípticas (KOSELLECK, 2007, p. 35-36).

Deste modo, o futuro desse progresso se caracteriza pela aceleração que se poria à nossa frente e ao seu caráter desconhecido. A aceleração tornar-se-ia uma tarefa de planejamento temporal, principalmente a partir do século XVIII e pós-Revolução, onde o vetor fundamental da moderna filosofia da história seria o cidadão emancipado do absolutismo e da Igreja.

Mas, isto só adviria através da arte do cálculo político, adquirindo seu refino ao longo dos séculos XV ao XVIII, sendo os pensadores do século XVIII, responsáveis sobremaneira pela mudança histórica abarcada pela Revolução. Resultado auferido pelo aprofundamento do pensamento iluminista, que acabaria por se conhecer como Século das Luzes. Pensamento este que tornaria o futuro um campo de possibilidades finitas, organizadas segundo o grau de probabilidade.

Eliminava, então, a certeza ideológica dos partidos religiosos da chegada de um Juízo Final e de uma única alternativa entre o Bem ou o Mal. Ou seja, o lluminismo introduzia a problemática da secularização no momento em que as ordens religiosas eram questionadas, além de denunciar as intromissões e injustiças promovidas pela instituição na política dos Estados.

\title{
Formatação de novos paradigmas
}

O pensamento iluminista tem como fundamentos a crença no poder da razão humana de compreender nossa verdadeira natureza e de ser consciente de nossas circunstâncias. 0 homem, então, creía ser o detentor de seu próprio destino, formulando o racionalismo e 
contrariando as imposições de caráter religioso, sua "razão" divina de existir, e os privilégios dados à nobreza e ao clero - ainda predominantes à época (séculos XVII e XVIII).

A preocupação com a ciência se originou do projeto de se fazer com que todo conhecimento fosse seguro. Seu bastião, René Descartes (1596-1650)3 , propugnava a busca por proposições das quais não se pudesse duvidar, questionando o "método antigo" de costumes transmitidos 4 .

Descartes desenvolveu um método contrário aos citados costumes: se imaginasse a existência de um dúvida - por menor que fosse - contida na afirmação de falsidade de um objeto, não o teria preliminarmente como falso, negando a dúvida e aquele que se propunha a negar, até que se eliminassem todas as dúvidas 5 .

O projeto iluminista esteve associado também a autores como Montesquieu (16891755), Rousseau (1712-1778), Kant (1724-1804), e aos empiristas ingleses Locke (1632-1704) e Hume (1711-1776). A liberdade individual se torna o centro da discussão sobre política, à medida que a filosofia política iluminista promovia a centralidade dos direitos individuais, diferenciando os compromissos dos antigos e medievais da ordem e hierarquia.

Nesse sentido, podemos afirmar que o iluminismo teve sua primeira expressão teórica, mais concentrada, em fins do século XVII, com o inglês John Locke - considerado o pai do liberalismo -, preocupado em "modificar" a concepção de súditos da coroa britânica para cidadãos. Defenderia a liberdade e a tolerância religiosa, além de fundar o empirismo - o qual todo pensamento deriva de alguma experiência.

A época vivenciada por Locke, e que resultou nos seus inúmeros trabalhos sobre a questão da liberdade, teria como ponto de influência o momento presenciado em vida. É nesse sentido que a Inglaterra vivia uma longa disputa entre a Coroa e o Parlamento - tendo como defensores da primeira, os Stuart e grande parte da nobreza e, da segunda, a burguesia ascendente, respectivamente. O país vivia uma grande guerra civil e de conturbação política, social e econômica, nos anos referentes entre 1640-1689, com a vitória das forças parlamentares sobre a absolutista.

É imerso nesse momento histórico que uma das grandes temáticas e de defesa do pensador inglês em suas obras consistiu em definir os direitos dos cidadãos e a responsabilidade do Estado para estes. Assim, buscou estabelecer o poder legislativo enquanto

\footnotetext{
${ }^{3}$ Disponivel em: http://www.consciencia.org/o-discurso-do-metodo-rene-descartes.

${ }^{4}$ Entende-se por "métodos antigos" os costumes transmitidos a gerações que não questionavam se esses mesmos costumes eram certos ou errados, dando, apenas, vida a eles mecanicamente

${ }_{5}^{5}$ Para maior aprofundamento, ver "O Discurso sobre o Método". Disponível em: http://www.consciencia.org/odiscurso-do-metodo-rene-descartes.
} 
primeira lei natural fundamental, pois este emanaria diretamente da sociedade - tendo caráter de poder supremo, acima do executivo e federativo.

Outro grande objetivo do ingresso dos homens em sociedade seria a posse da propriedade em paz e segurança, onde as leis estabelecidas nessa sociedade protegeriam 0 indivíduo. Esse poder teria caráter pétreo nas mãos da comunidade, uma vez que o tenha declarado. Assim, não poderia qualquer edito, ter a força e a obrigação de uma lei, se não tiver a sanção do legislativo, escolhido e nomeado pelos cidadãos. ${ }^{6}$

O pensamento lockeano acabou, também, por influenciar uma gama de intelectuais europeus, que discordavam da situação política no continente. Entre as nações européias, é na França, pré-1789, onde o pensamento liberal encontrou grande aceitação e divulgação de seus ideais. Nesse processo de aprofundamento filosófico da teoria, angariaram grande exposição, dois franceses: Montesquieu (1689-1755) e Jean-Jacques Rousseau (1712-1778).

O primeiro - citado logo acima - abarcou respeitabilidade e uma visão avançada a partir de suas obras "Cartas Persas" e, principalmente, em "O Espírito das Leis". "Cartas Persas" foi uma obra de ficção escrita sob forma de cartas por um persa de passagem pela Europa à seus familiares que se encontravam em seu terra de origem. Essa obra, tem como relevância a tentativa do autor de desprender-se dos valores europeus culturais, emocionais e políticos e ver o continente de um ponto de vista externo - abarcado pelo estranhamento do viajante com a civilização européia e as diferenças;

Já "O Espírito das Leis" é vista como uma obra de importância ímpar na história da filosofia liberal, o qual defendia a divisão do poder político em Legislativo, Executivo e Judiciário, vindo ser a primeira a desenvolver a teoria da divisão de poderes, supracitados. Outra característica do pensamento de Montesquieu, de acordo com Althusser (1977, p. 24), é que

\begin{abstract}
A necessidade que governa a história, para começar a ser científica, deve deixar de beber a sua razão em qualquer ordem que transcenda a história. É portanto necessário varrer do caminho da ciência pretensões de uma teologia ou de uma moral que pretenderiam ditar-lhes leis. (...) Não é a teologia que cabe enunciar a verdade dos factos da política. (...) introduzir a teologia em história, é confudir as ordens e misturar as ciências.
\end{abstract}

Assim, Montesquieu buscava tentar explicar as leis e instituições humanas, sua permanência e evolução, através de leis da ciência política. Ou seja, tirava as leis de uma ordem natural, emanadas de Deus e imutáveis, para afirmar que é uma formulação humana, rompendo com a tradicional submissão da política à teologia.

\footnotetext{
6 Para uma análise mais aprofundada da visão de Locke, ver: Locke (1998); Weffort (1999); Bonavides (2001); Filho e Barros (2008).
} 
Rousseau se destacou entre os filósofos do "Século das Luzes" por suas críticas ao processo de evolução da ciência, assim como pela condição do povo nas questões políticosociais. Assim, afirmaria acidamente que a ciência e a ideia de progresso inconteste, promulgada por pensadores desde o século XV e aprofundada no pensamento iluminista, havia se corrompido. Para ele, ela não tinha produzido avanço significativo para a sociedade ao todo. Entretanto, isto não caracterizaria como uma recusa, mas sim com 0 intuito de um aprimoramento de seu ideal.

Ou seja, para Rousseau (1985, p. 09),

O que há de mais cruel é que todos os progressos da espécie humana distanciam-na cada vez mais de seu estado primitivo, quanto mais acumulamos novos conhecimentos, tanto mais nos privamos dos meios de adquirir o mais importante de todos, e que é, de certa forma, de tanto estudar o homem que perdemos a capacidade de conhecê-lo.

Tratou exaustivamente sobre diversos temas da filosofia política, como o estado civil, da liberdade civil e entre o governo e o soberano7. 0 que o colocaria em destaque entre os que inovaram no pensamento político estaria a defesa da concepção do exercício da soberania pelo povo, como garantia para sua libertação. Afirmaria que

a primeira e mais importante consequência dos princípios acima estabelecidos está em que somente a vontade geral tem possibilidade de dirigir as forças do Estado, segundo o fim da sua instituição, isto é, o bem comum. ${ }^{8}$

O autor do projeto de paz perpétua definiu soberania não como independência, mas como liberdade moral, o que vem a derrubar a incompatibilidade entre a soberania e a participação em uma confederação com outras soberanias. É através da possibilidade de fazer 0 que se pretende sem oposição, sem temer os resultados e sem ofender ninguém, que se tem maior liberdade, ou seja, a independência de uma soberania se realiza quando numa sociedade em que há confiança, segurança e justiça entre as partes: "when no sovereign is able to offend the common interests, each can be 'free' as well as 'independent'”(ROUSSEAU apud AIKO, 2006).

Tendo isso em vista, a soberania seria um exercício da vontade geral, a qual jamais poderia se tornar fruto de alienação. Ela viria a balizar e dar assistência na formatação de um estado democrático, que garantisse o viés da igualdade para todos os cidadãos.

É nesse sentido, que o movimento lluminista surgia pela França em meados do século XVII, e defendendo o domínio da razão sobre a visão teocêntrica que predominava na Europa

\footnotetext{
${ }^{7}$ Não será tratado nesse artigo outros pontos levantados por Rousseau - como a questão do estado de natureza, contrato social, etc. -, em vista da temática proposta por este trabalho.

${ }^{8}$ Ver em: ROUSSEAU. Jean-Jaques. 0 Contrato Social. Disponível em: <http://www.cfh.ufsc.br/ wfil//contrato.pdf>
} 
desde a Idade Média. Esta forma de pensamento advinha fortemente dos ideais liberais e tinha como propósito, o de iluminar as "trevas" em que se encontrava a sociedade européia dos regimes absolutistas.

Os filósofos que defendiam estes ideais - tratados anteriomente -, acreditavam que 0 pensamento racional deveria se sobrepor às crenças religiosas e ao misticismo, predominantes àquela época, e que, segundo eles, bloqueavam o progresso do homem. Nesse sentido, 0 homem deveria ser o centro e passar a buscar respostas para as questões que, até então, eram justificadas somente pela fé.

A filosofia iluminista se prostrava otimisticamente, pois acreditava no progresso por meio do uso crítico e construtivo da razão, sendo o homem o detentor de seu próprio destino e formulador do racionalismo. Por esta perspectiva, contrariavam as imposições de caráter religioso, ao absolutismo e sua "razão" divina, além dos privilégios dados à nobreza e ao clero

O movimento atingiria o seu apogeu no século XVIII, o qual passaria a ser conhecido como o "Século das Luzes". O lluminismo encontrou maior força e recepção aos seus princípios na França - palco de problemas econômicos, religiosos, políticos e sociais -, onde influenciaria sobremaneira a Revolução Francesa através da: "Liberdade, Igualdade e Fraternidade" - lema basilar no processo revolucionário.

É através destas formulações teóricas que tornou possível transportar para a realidade histórica - antes dominadas pelo pensamento clerical e escatológico -, ficções como o império que deveria durar mil anos ou a sociedade sem classe. Seria necessário um indicativo histórico, que visasse ultrapassar os prognósticos racionais, relativizando o projeto dessa mesma filosofia.

Portanto, é a partir destas percepções que a Revolução Francesa poderia ser vista como a última grande querela dos antigos e dos modernos: querela política, focalizada sobre a questão da liberdade, mas onde, no fundo, cada qual se pretendia moderno. É nessa perspectiva, que os revolucionários se lançavam a fio para se tornarem plenamente moderno, lançando mão das "antigas repúblicas" (KOSELLECK, 2007).

\section{Revolução e Mudança na Perspectiva Histórica}

A construção e o estabelecimento dessas perspectivas de visão de mundo viriam a influenciar os movimentos revolucionários, tendo a Revolução Francesa como marco histórico 
desse rompimento. Outra marca do pós-1789 na concepção de revolução, seria a introdução da "experiência", da "esperança", do "progresso" e do "escopo universalista", de cunho epocal.

Assim, esta Revolução se diferenciaria das demais revoluções liberais ocorridas - caso da Americana, em um grau menor, e, em maior relevância, da Inglesa - pela sua forma e por seus ideais fundamentais. Traria em suas reivindicações, movimentos de cunhos sociais descontentes com a exclusão e opressão das populações não-privilegiadas. Se basearia, não apenas de uma mudança social, mas de mudança social com caráter de emancipação caracterizando como uma nova era das "sociedades".

Portanto, para entender este processo, o atual capítulo buscou lançar mão de uma pesquisa acerca do movimento revolucionário francês, detendo-se numa análise do Terceiro Estado e sua densa participação no processo. Além disto, visou-se examinar o arcabouço conceitual trazidos pelo iluminismo, sua influência pré e pós-Revolução Francesa e a ascensão do universalismo, que levariam a cisão com os ideários até então predominantes.

\section{Terceiro Estado}

Na vigência do Antigo Regime, na França, os Estados Gerais representavam o reino em épocas de conturbações políticas, sociais, religiosas ou econômicas. A datação da primeira atuação dos Estados Gerais pode ser creditada em 1483, pelo falecimento de Luís XI, os quais foram convidados a emitir um parecer acerca da organização da regência. Foram ainda reunidos em 1560, na tentativa de remediar uma crise financeira; em 1576-77 e 1588-89, por motivos de questões religiosas, e; em 1614, pelo assassinato de Henrique IV, levando, consequentemente, a uma rebelião.

No entanto, os Estados Gerais só deviam suas reuniões a partir da iniciativa do governo que os mantinham ou os extiguiam, conforme bem entendesse. Estes não detinham, portanto, poder decisório no reino, tornando-se mais em uma representação com intuito de prover consenso ao monarca, ao qual daria subsídios e apoio a decisões políticas e econômicas tomadas pelo regente.

Os Estados Gerais ficariam inativos por mais de um século, em vista do fortalecimento e consolidação do regime monárquico, no reinado de Luis XIV (1643-1715). Este tipo de regime alcançaria tanto o seu ponto máximo como também a sua decadência. Pois, não haveria mais de ter os meios necessários para o provimento da evolução econômica e produtiva exigidas por sua época, tendo o regime feudal já cumprido o seu tempo (MANFRED, 1965, p. 08). 
Só em fins do século XVIII - mais precisamente em 1788 - que o rei Luis XVI convocaria os seus "Estados". Assim como das outras situações constatadas anteriormente, esta adviria de uma crise sistêmica. Crise esta, baseada no estrangulamento do regime absolutista, além dos problemas de cunho produtivo como: déficit financeiro, escassez de gêneros alimentícios e pressão popular.

É nas palavras de Hobsbawm (2007, p. 90) que se percebe a tentativa desta instituição e sua respectiva queda, a qual

\begin{abstract}
A primeira brecha no fronte do absolutismo foi uma "assembléia dos notáveis" escolhidos a dedo, mas assim mesmo rebeldes, convocadas em 1787 para satisfazer as exigências governamentais. A segunda e decisiva brecha foi a desesperada decisão de convocar os Estados Gerais, a velha assembléia feudal do reino, enterrada desde 1614. Assim, a revolução começou como uma tentativa aristocrática de retomar o Estado. Esta tentativa foi mal calculada por duas razões: ela subestimou as intenções independentes do 'Terceiro Estado' - a entidade fictícia destinada a representar todos os que não eram nobres nem membros do clero, mas de fato dominada pela classe média - e desprezou a profunda crise socio-econômica no meio da qual lançava suas exigências políticas.
\end{abstract}

É inserido nessa conturbação política e por pressão dos parlamentos que exigiam que, qualquer reforma tivesse o crivo dos Estados-Gerais. Acabaria isto por gerar outros tipos de reivindicações, como a ascensão de um ator inédito na respectiva conjuntura: o Terceiro Estado. Buscaria uma maior representação no interior da instituição, aspirando uma igualdade as outras duas ordens e tentar pôr em prática sua preponderância pelo voto individual.

Esse número de demandas promovidas pelo Terceiro Estado era em vista de sua inoperância em relação ao Primeiro e Segundo Estado. As duas primeiras ordens tinham preponderância sobre o poder popular, visto que a forma de votação dos "Estados" se dava por ordens e não por voto individual - caracterizado como a grande reivindicação das camadas mais baixas. Esse detrimento também pode ser visto pelo número que cada Estado representava na nação.

É nesse sentido que Siyés (1943, p. 62-65) analisa os números de representados referentes a cada ordem e a disparidade destes na realidade social francesa. Assim, o Primeiro Estado - formado pelo clero -, representava 80.400 eclesiásticos. Já o Segundo - formado pela nobreza -, tinham na sua base 110.000 nobres. Por último, o Terceiro detinha entre 25 a 26 milhões de pessoas na nação - abarcadas em sua amplitude por camponeses, pequenos burgueses e artesãos ${ }^{9}$.

\footnotetext{
9 Para um aprofundamento acerca do Terceiro Estado, ver: SIEYĖS. (1943), Que es el Tercer Estado? Buenos Aires: Editorial Americalee.
} 
Essa desproporção seria responsável pela maior parte das exigências da ordem inferior, assim como a presença de princípios liberais em seu escopo basilar. Haveria então uma pressão para o Terceiro Estado convocar e compor a Assembléia Nacional, pois teria a procuração da maioria. Também estaria garantido na razão e na equidade, buscando garantir os direitos civis e políticos, já que nenhuma das outras ordens seriam representantes da nação. Portanto, 0 movimento posto pelo Terceiro Estado seria o "pontapé” inicial para Grande Revolução.

\section{A Revolução}

A França vivia no extremo de uma revolução, devido às situações sociais, à enorme insatisfação popular e crise econômica. Somando-se as exigências do Terceiro Estado e sua maior atuação com o povo, ficou uma situação insustentável para o absolutismo. É nesse sentido que a população, em 14/07/1789, tomaria o poder e destronaria a monarquia, comandada pelo rei Luis XVI, marcando o início do processo revolucionário. Tomariam como primeiro alvo a Bastilha, prisão política e símbolo da monarquia francesa.

No desenrolar da guerra civil, a Assembléia Constituinte inicia reunião com intuito de dar provimento ao movimento. Os deputados aprovariam a abolição dos direitos feudais como: as obrigações devidas pelos camponeses ao rei e à lgreja; as obrigações devidas aos nobres, e; 0 cancelamento de todos os direitos feudais sobre o campesinato.

Em menos de um mês após a queda da Bastilha - mais exatamento no mês de agosto de 1789 -, a Assembléia Constituinte promulgaria a Declaração dos Direitos do Homem e do Cidadão. Este documento, de importância ímpar, trazia em seu escopo significativos avanços sociais, garantia de direitos iguais aos cidadãos e maior participação política para o povo. Além destes avanços, ele teria grande repercussão pela sua intenção de se tomar como um preceito universal.

Com o aprofundamento da revolução, o rei Luis XVI tentou fugir em meados de 1791, mas sendo capturado ainda na França. Com o receio de que o movimento se espalhasse pelo continente, diversos países começam a movimentar-se para sufocar a revolução. Entretanto, a ameaça de invasão acabava por aumentar a radicalização interna, que desembocaria na época do Terror.

Mas é relevante ressaltar que nem todas as situações de extremo perigo nacional levam os povos ao Terror revolucionário. A verdade é que o Terror faz parte da ideologia revolucionária, na qual supervaloriza o sentido das "circunstâncias". Não há circunstâncias 
revolucionárias, mas sim, uma Revolução que se alimenta de circunstâncias. As "circunstâncias" formam o terreno sobre o qual esse sistema se desenvolve e ocupa a esfera do poder, produzindo o tecido factual da história da Revolução (FURET, 1989).

Nesse sentido, os girondinos ${ }^{10}$ eram, desde o fim de 1791, os apóstolos mais eloquentes da guerra contra o monarca, por estarem convencidos que esta é a condição de seu poder, tendo à sua frente Robespierre ${ }^{11}$. E, o extremo perigo nacional daria uma aparência de justificação racional à conspiração dos adversários e às violências da repressão. Esse tipo de situação constituiria num terreno favorável à intensificação da guerra civil e o derramamente de sangue, perdendo a revolução sua razão inicial. Não teria, à época, nenhum lugar para a política, além do consenso ou da morte.

É durante esse processo revolucionário, que grande parte da nobreza deixa a França, além da tentativa de fuga da família real. Preso os integrantes da monarquia, entre eles o rei Luis XVI e sua esposa Maria Antonieta, tiveram como destino a guilhotina em 1793. Tornava-se 0 regicídio na França o segundo acontecimento na história do continente europeu. 0 clero também não sairia impune, tendo os bens da Igreja confiscados.

Mas, com a intensificação e o receio dos rumos tomados pelas medidas da Salvação, Robespierre acabava por ser deposto. Assim, buscou-se restaurar a legitimidade representativa, tão expressada na raiz da revolução. Eles, portanto, fizeram mais que parar o "Terror", 0 desmoralizam como forma de poder. No entanto, ainda apelariam a ele, envergonhadamente, em certos momentos, como se fosse um expediente e não mais um princípio. Este episódio ficaria conhecido como "9 Termidor" - revolta contra a política do Terror.

O "9 Termidor" colocaria colocaria fim à exclusão das massas no governo da República. Essa participação era completamente inexistente na ditadura robespierrista, a qual esse sistema de poder que os conjurados derrubam, não mais seria utilizado. Portanto, se o Terror tornou-se "impossível" após "9 Termidor", isso se deveu simplesmente ao fato de a sociedade ter recuperado sua autonomia em relação à situação política.

Mas seriam outros acontecimentos que fariam a Revolução Francesa perdurar como a promotora e detentora destes paradigmas. Seria, portanto, só após o seu estrondar que a sociedade ocidental se assentaria sobre as suas bases.

\footnotetext{
10 Os Girondinos eram os deputados de um departamento do interior da França, a Gironda, área próspera da costa atlântica, tendendo a representar os interesses comerciais e a visão de mundo da burguesia francesa.

11 Robespierre fazia parte do Clube dos Jacobinos, a ala mais radical dos revolucionários. Foi um dos que pediram a condenação do rei Luís XVI, em 1793. Em julho do mesmo ano, Robespierre criou o Comitê de Salvação Pública para perseguir os inimigos da revolução, ficando conhecido como o regime do "Grande Terror".
} 


\section{Ruptura Paradigmática}

É a partir da Revolução Francesa que haveria a possibilidade de desenhar um espaço político inédito, invocando-se ao mesmo tempo os heróis da Antiguidade e recusando sua imitação, em nome da proclamada e inovadora revolução. Assim, a Antiguidade invocada, era uma figura de ruptura e também tranqüilizadora, pois procuravam fazer com que o passado viesse para o presente, com intuito de se fazerem reconhecidos e exprimir o inédito de sua própria ação.

Assim, derrubaria por completo o regime absolutista feudal, além de golpear a feudalidade mortalmente, abrindo espaço para o progresso capitalista. Ao mesmo tempo, a revolução destruiu as relações de produção medievais e harmonizaria as novas formas de produção advindas da Revolução Industrial. A Revolução francesa, inauguraria, então, a livre iniciativa privada - em detrimento da idéia do público - e a consolidação do desenvolvimento capitalista.

O exército teria a sua criação e consolidação a partir da revolução, perdendo o caráter de voluntarismo. Esse "voluntarismo" era representado pela nobreza, a representante e detentores dos altos cargos da instituição. Com o fim desta política de organização militar, se instalaria na instituição o convocamento obrigatório, estendido para todos os homens da nação.

Outra mudança seria o fim dos privilégios e a diferenciação por castas na sociedade francesa - e logo depois espalhada pelo ocidente. Seria introduzido a concepção da meritocracia, em detrimento dos títulos nobiliárquicos. Ou seja, a forma de ascensão social, econômica ou política se daria não mais por títulos, mas sim pelo mérito pessoal, intransferível.

O indivíduo se tornaria o ente máximo no e pós-Revolução, tornando-se os detentores de direitos, como indicado pela "Declaração dos Direitos do Homem e do Cidadão", aprovada pela Assembléia Constituinte Francesa em 26/08/1789. Segundo os preceitos de que "os homens nascem e permanecem livres e iguais em direito; a associação política tem por finalidade assegurar a liberdade, a propriedade, a segurança e a resistência à opressão.

Assim, o indivíduo exprimiria a afirmação e a sua liberdade a um grupo, à sociedade e ao Estado. Diferentemente à época medieval, onde o indivíduo era visto como parte do coletivo, não sendo destacável do todo, a Revolução quebraria uma vez por todas com esse pensamento. 
O homem seria colocado como o centro do universo, livre e responsável pelos seus atos, além de base para implementação de um Estado democrático.

Caberia então, elaborar a distância entre uma nação moderna e as pequenas repúblicas da antiguidade, entendendo a liberdade dos antigos e a liberdade dos modernos. Nesse intuito, a liberdade moderna seria nada menos que a liberdade civil/individual e a liberdade antiga, a participação coletiva dos cidadãos no exercício da soberania.

A ciência, portanto, seria atingida por um novo paradigma, abarcada por uma dimensão social e pessoal, atingindo as regiões mais profundas da existência humana. Perderia o os valores eclesiásticos, predominantes em seu pensamento pré-liberais. O Universo perderia o seu encanto. Além de ser despojado das suas características mais significativas, que dariam, subjetivamente, sentido à vida como um todo.

Era cavado, portanto, uma distância longínqua entre o homem antigo e o moderno. Em relação ao primeiro, respectivamente, fonte de uma participação ativa e constante do poder coletivo; já ao segundo, fruto de uma soberania que já não era mais que uma suposição abstrata, obtendo o gozo sossegado da independência privada.

\section{Considerações Finais}

O presente trabalho busca analisar a Revolução Francesa e suas mudanças de paradigmas na sociedade ocidental. Fruto dessas mudanças paradigmáticas encontra-se a evolução do pensamento liberal e suas vertentes, como grandes responsáveis pelos movimentos de ruptura no sistema internacional e de Estados, além da subjetividade do pensamento humanístico, que desembocaria no que conhecemos como modernidade.

Como elencado, a ideia de modernidade surge através da possibilidade de separação entre 0 antigo e passado, pelo presente e moderno. Essa separação visava relatar os antagonismos entre as duas "épocas" e suas mudanças conceituais acerca de/do mundo.

$\mathrm{O}$ antigo, representado pelo pensamento clerical e sustentados pela ideia da escatologia e da providência divina, visaria à manutenção de um status quo da lgreja sobre a sociedade. Preponderância esta, baseada no medo como uma forma de dominação do imaginário coletivo. Teria este como ponto principal a afirmação da brevidade do fim dos tempos.

O pensamento liberal e os filósofos - e claro, dos cientistas do renascimento até 0 Século das Luzes - representantes do lluminismo, viriam a romper com essa forma de 
pensamento pré-Revolução Francesa, até então dominante. Colocaria o homem no centro do universo, tirando a concepção da providência divina dos acontecimentos históricos. 0 indivíduo também surgiria como um ente a parte, tendo sua importância elevada a maior nível.

A Revolução Francesa seria esse marco histórico, como fator chave de ruptura paradigmática no pensamento ocidental. A Igreja perderia o espaço na sociedade como fonte do "saber", ficando relegada na incumbência de transmissão da fé - sem mais indícios de uma factualidade crível ou científica. Assim, a ciência se destacaria como detentora e promotora da construção dos saberes.

Nesse sentido, a modernidade teria incrustado na sociedade as formas de pensamento trazidas pelo pensamento liberal, em sua maior parte. Tendo o homem saído de um mero expectador dos acontecimentos históricos, políticos e sociais - base do pensamento eclesiástico - , para um agente ativo e indutor das ações humanas. Portanto, o homem tomaria para si as "rédias" dos novos rumos da sociedade levando a concepção de progresso as ciências - físicas, sociais e humanas.

\section{Referências Bibliográficas:}

1. ADORNO, Theodore; HORKHEIMER, Max. Dialética do Esclarecimento. Rio de Janeiro: Editora Zahar, 1985.

2. AlKO, Yuichi. "Rousseau and Saint-Pierre's peace project: a critique of 'history of international relations theory'". In: JAHN, Beate (Org.). Classical theory in international relations. Cambridge: Cambridge University Press, 2006. p. 96-120.

3. ALTHUSSER, Louis. Montesquieu, a Política e a História. Lisboa: Editorial Presença, 1977.

4. BOBBIO, Noberto. Liberalismo e Democracia. São Paulo: Brasiliense, 2005.

5. BONAVIDES, Paulo. Do Estado Liberal ao Estado Social. São Paulo: Malheiros Editores, 2001.

6. DELUMEAU, Jean. História do Medo no Ocidente. São Paulo: Companhia das Letras, 2009.

7. DRAY, William. Filosofia da História. Rio de Janeiro: Ed. ZAHAR, 1977.

8. DUPAS, Gilberto. O mito do progresso. São Paulo: UNESP, 2006.

9. DURKHEIM, Emile. "Como Montesquieu classifica as sociedades por tipos e espécies". In: QUIRINO, Célia Galvão. SOUZA, Maria Tereza Sadek R. de. O pensamento político 
clássico: Maquiavel, Hobbes, Locke, Montesquieu, Rousseau. São Paulo: T. A. Queiroz, 1980.

10. FERNÁNDEZ-ARMESTO, Felipe. WILSON, Derek. Reforma: o cristianismo e o mundo 1500-2000. Rio de Janeiro: Record, 1997.

11. FURET, François. OZOUF, Mona. Dicionário Crítico da Revolução Francesa. Rio de Janeiro: Nova Fronteira, 1989.

12. HARTOG, François. Os antigos, o passado e o presente. Brasília: Ed. UNB, 2003.

13. HOBSBAWM, Eric. A Era das Revoluções: Europa 1789-1848. Rio de Janeiro: Paz e Terra, 2007.

14. JAPIASSU, Hilton. "Como nasceu a ciência moderna?" In: JAPIASSU, Hilton. Nascimento e Morte das Ciências Humanas. Rio de Janeiro: F. Alves, 1982.

15. JAPIASSU, Hilton. Nascimento e Morte das Ciências Humanas. Rio de Janeiro: F. Alves, 1982.

16. KOSELLECK, Reinhart. Futuro Passado. Rio de Janeiro: CONTRAPONTO, 2006.

17. LOCKE, John. Dois Tratados sobre o Governo. São Paulo: Martins Fontes, 1998.

18. MANFRED, A. A Grande Revolução Francesa. São Paulo: Ícone Editora, 1986.

19. ROUSSEAU, Jean-Jacques. Discurso sobre a origem e os fundamentos da desigualdade entre os homens. Tradução Iracema Gomes Soares; Maria Cristina Roveri Nagle. Brasília: Ed. UnB, 1985.

20. ROUSSEAU, Jean-Jaques. Do Contrato Social. Disponível em: <http://www.cfh.ufsc.br/ wfil/contrato.pdf>. Acessado em 20 de julho de 2010.

21. SANTOS, Boaventura de Sousa. Um Discurso sobre as Ciências. São Paulo: Editora Cortez, 1987.

22. SIEYĖS. Que es el Tercer Estado? Buenos Aires: Editorial Americalee, 1943.

23. SILVA, Marco Antonio de Meneses. "Teoria Crítica em Relações Internacionais". Contexto Internacional. Rio de Janeiro: PUC, Vol. 27, nº2, pp. 249-282, 2005.

24. WALLERSTEIN, Immanuel. O Universalismo Europeu: a retórica do poder. São Paulo: Boitempo Editorial, 2006.

25. WEFFORT, Francisco C. (Org.). Os Clássicos da Política. São Paulo: Ed. Ática, 1999. 